\title{
MANAGEMENT PRACTICE OF CINNAMOMUM TAMALA IN ELADI VDC OF SYANGJA, NEPAL
}

\author{
Mahendra Singh Thapa and Baburam K.C. \\ Institute of Forestry, Pokhara campus, Tribhuvan University, Nepal \\ msthapa@iofpc.edu.np
}

\begin{abstract}
Cinnamomum tamala is a moderate sized evergreen tree species which is used as spices in Indian subcontinent. In Nepal, it is found between 500- $2000 \mathrm{~m}$ above sea level. Its English name is Indian cassia lignea or Cinnamon. Leaves and bark of the species contain aromatic oil and are used as spices. The status and distribution of this species has less explored so this study has been carried out to assess the resource base and management practice at Eladi VDC of Syangja district. The researcher estimated the existing stand of Sinkauli, its annual increment, the annual allowable harvest, density, relative density, frequency, relative frequency and abundance along with its ethnobotanical uses. Community forests, National forest and private forest consisting of Sinkauli stands were inventoried based on the stratified random sampling. The scattered trees in the farmland and marginal land were enumerated and mesured. The measurement of DBH were stratified into different size groups at the interval of $5 \mathrm{~cm} \mathrm{DBH}$ class and at 5 years interval of age classes. Altogether 98 trees were sampled from 0.14 ha area. For the measurement of fresh weight and air-dried weight of bark and foliage, thirty two sample trees representing the Sinkauli stand, were felled and measured.

Data were analyzed by using different statistical tools like mean, diagrams, flowcharts, and pie chart. The density, relative density, frequency, relative frequency, abundance and growing stock are 13171, $55.34 \%, 100 \%, 11.7 \%, 13171,700$ trees/ha respectively. The air-dried weight to fresh weight ratio of bark of C. tamala is found to be 0.5210 and that of leaf is 0.5721 . From this VDC, 345 trees of average age could be harvested with which $2944 \mathrm{~kg}$ bark and $2409 \mathrm{~kg}$ of leaves could be extracted annually. Based on the existing price at the local market, Rs 1177,60 from bark (RS 40/ Kg) and Rs 36130 from foliage (Rs 15/ Kg) could be earned annually.

As people are less aware about the importance of C.tamala and the resource is dwindling from natural stand, the awareness program for its proper management, cooperation among different stakeholders, provision of economic market, and development of proper monitoring and evaluation program are recommended for the sustainable management of C.tamala stands.
\end{abstract}

Key Words: Annual allowable harvest, demand, growing stock, management, supply

\section{INTRODUCTION}

Cinnamomum tamala, which belongs to Lauraceae family, is a moderate sized evergreen tree species. But another species Cinnamomum zeylamicum, which is mostly called as Dalchini, is not found in this District. Its local name is Sinkauli. Some people call it as Dalchini while some even call it as Tejpat. But in general, bark of Sinkauli is the Dalchini and the leaves are Tejpatta. Its English name is Indian cassia lignea or Cinnamon.

Leaves are opposite with three veins running from the base to the apex, $10-15 \mathrm{~cm}$ long, lanceolate to ovate with short blunt pointed in 
panicle, $5-10 \mathrm{~cm}$ long, fruit about $1 \mathrm{~cm}$ across in a shortly lobed cup and black, ovoid, flower is pale -yellow, pubescent in panicle. Barks are dark brown. Flowering season is March -May and fruit ripens between June and October. Leaves and bark of the species contain aromatic oil and are used as spices in the Indian subcontinent.

\section{Distribution:}

It is distributed in tropical and sub-tropical Himalayas (3000 to $8000 \mathrm{ft}$ ) and in Eastern Bengal (Edwards 1993). In Nepal, it is found between 500- $2000 \mathrm{~m}$ above sea level (Jackson 1994). It is found on Kashmir, Assam , Bhutan and mainly occurs in the mid-western region of Nepal such as Pyuthan, Salyan, Surkhet, Dailekh, Jajarkot, Rukum and somewhere sparsely in Palpa district (Koldanda and Masyam VDCs).

\section{Aspect:}

Northern aspect is much favorable than southern aspect. Moist shady especially, stream side and $k$ holsa kholsi are favorable for its proper growth and development. It prefers well drained moist soil.

\section{Associates:}

Associated species of it are Mahuwa (Madhuca indica) Bhimal (Grewia opposetifolia), Chilaune (Schima wallichi), Katus (Castanopsis indica) Chiuri (Aesandra butyraceae), Tiju (Diospyrous melanoxylon), Chutro (Berberis aristata), Rittho (Sapindus mukorossi), Amala (Emblica officinalis), Kalikath (Myrsine semiserrata), Baklapate (Vibernum cotinifolium), and so on species. Its propagation can be made from seed, branch cutting and coppicing.

This species is growing in community forests, private lands (homestead land) and is managed by local people. It is extracted from forests, used locally and marketed. Edward (1993) documented that plants are raised from seed in Nursery bed during March and April. Seeds germinate in 30 to 40 days after sowing and transplanted when 4 to 5 years old in the field in rows $7 \mathrm{ft}$ apart, the spacing between plants being 10 to $11 \mathrm{ft}$. sufficient shades is provided in the early stage of the growth, and harder trees are cleared after 8 to 9 years. In India leaves are ready for harvesting when trees are 10 years old, and then continue to bear for a century (Edward 1993). Leaves are collected every year from vigorous tree and in alternate year from old and weak ones. Best time for leaf collection is during dry weather from August - October. In Nepal, farmers usually extract the bark from the bole of the trees between March and October because the bark leaves off the cambium easily and thus it is easy to work. The age of extraction varies according to the growth of tree that is obviously depending on the fertility of site. From the conservation point of view, this species has not prohibited for its cultivation, transportation and exportation by the government; however the population of this species is continuously depleting on the common lands due to the lack of scientific management. So, the main aim of this study was to assess the status and management practice of Cinnamomum tamala being carried out by the local people in the community forests and in farmlands.

\section{MATERIALS AND METHODS}

The study was conducted in Eladi VDC of Syangja District. Both the primary and secondary data were collected for the purpose. Participatory resource mapping, rapid vegetation assessment (RVA), key informants interview, direct observation and resource inventory were done. To assess the distribution pattern and stock, whole area was first divided into fourteen blocks based on the land ownership and effective area was calculated. Sampling intensity taken was approximately $1.8 \%$ of the total effective area. 
Plot method with the stratified random sampling was carried out. Plot size was $10 \mathrm{mX10m}$ for pole and $5 \mathrm{mx} 5 \mathrm{~m}$ for regeneration, shrubs and herbs. Only two dimension i.e. DBH and height were recorded for pole sized tree and regenerations were enumerated.

\section{Data analysis}

Descriptive or qualitative data were analyzed through direct observation participatory discussion, questionnaire survey, field measurement, interview with local people and key informants and collection of official records. Quantitative data were analyzed through simple mean, percentage, bar diagrams, tables and pie charts.

Different formulae were used to calculate different biophysical data

1. Density and Relative density:

Density of Sinkauli $=\frac{\text { Total no. of individuals of Sinkauli }}{\text { Total no. of plots sampled } \times \text { area of a plot }}$ Relative density of Sinkauli $=\frac{\text { Density of Sinkauli }}{\text { Total density }}$

2. Frequency and Relative frequency:

Frequency of Sinkauli $=\frac{\text { No. of plots in which Sinkauli occurs }}{\text { Total No. of plots sampled }} \times 100 \%$ Relative Frequency of Sinkauli $=\frac{\text { Frequency value of Sinkauli }}{\text { Total frequency value of all species }} \times 100 \%$ 3. Abundance of Sinkauli $=\frac{\text { No. of Sinkauli in all quadrates }}{\text { No. of quadrates in which Sinkauli occurred } \times \text { size of quadrates }}$

4. Growing stock of C. tamala was calculated in terms of its density (no. of trees per ha).

5. Leaf and bark Biomass of the species was calculated by destructive sampling of two age and diameter class. The fresh and air dry weight of the leaf and bark was taken with a weighing machine in the field.

\section{RESULTS AND DISCUSSIONS}

\section{A. Abundance, Frequency, Relative Frequency, Density and relative Density of Cinnamomum tamala}

\section{Pole Stratum}

Out of the effective area of 7.72 hectares of the Sinkauli forest, 0.14 ha was taken as a sample area with $1.82 \%$ sampling intensity. Altogether 14 plots were sampled where 98 trees of Sinkauli, 33 trees of Chilaune, 33 trees of Katus, 25 trees of Bakle, 9 trees of Tiju, 5 trees of Mahuwa and a single tree of Siltimur were measured. The plot size for this stratum was taken $10 \times 10 \mathrm{~m}^{2}$ and the total number of trees measured was 204 having total volume of $34.48 \mathrm{~m}^{3}$. From this calculation about $48.03 \%$ of total stand were of C. tamala having $43.5 \%$ volume of growing stock. The Abundance and total growing stock is 1813 and $1458 \mathrm{~m}^{3}$ respectively. The relative frequency and relative density of different species is shown in the figure.

From the chart above, the relative density of C. tamala is almost $49 \%$ whereas relative density of Chilaune and Katus is same (16\%). Similarly, the relative density of Bakle and Other miscellaneous species is $12 \%$ and $7 \%$ respectively.

Relative Density of different species

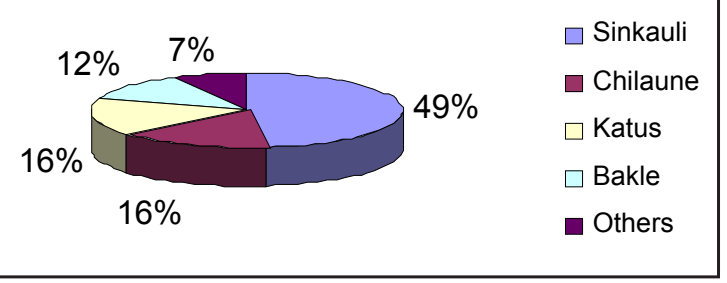

Relative Frequency of Different Species

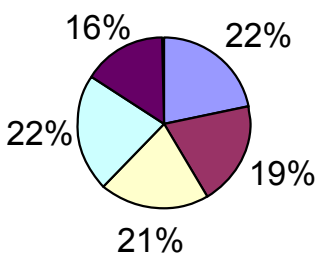

Sinkauli

$\square$ Chilaune

$\square$ Katus

$\square$ Bakle

$\square$ Others

Here, the relative frequency of Sinkauli and Bakle is same i.e. $22 \%$ then Katus, Chilaune and others have 
$21 \%, 19 \%, 16 \%$ relative frequency respectively.

\section{Regeneration Stratum}

From the calculation, the density of C.tamala was found to be 13171 plants and its relative density was $55.34 \%$.Since Sinkauli plants were found in all 14 quadrates, its frequency is $100 \%$ securing $11.76 \%$ relative density. The growing stock of all species is $23800 \mathrm{~m}^{3}$ per hectare out of which Sinkauli occupies $13171 \mathrm{~m}^{3}$. The relative density and relative frequencies of different species are shown as below.

From this figure, it is concluded that Sinkauli has the highest relative density of $55 \%$ where as Katus has least (4\%) relative density. The relative density of Tiju, Bakle and Others are $14 \%, 6 \%$ and $20 \%$ respectively.

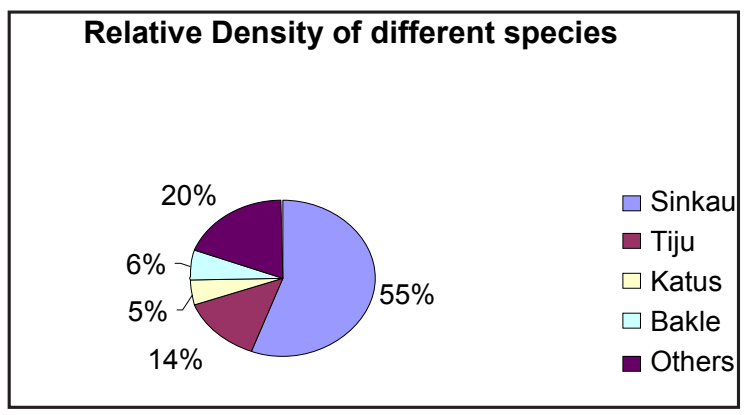

From the above figures, in the two different strata, the relative density of $C$. tamala in the pole strata is $48.03 \%$ while it is $55.34 \%$ in the regeneration stratum. It is also concluded that relative Frequency of C.tamala in pole stratum is almost double than in the regeneration stratum. It is due to the lack of proper thinning and cleaning of the forest. There was a thick pile of leaf litter which might be preventing the seed from regenerating. Eating of seed by the winter migratory bird called as Hukus could be another possible reason for this situation.

\section{Relative Density of different species}

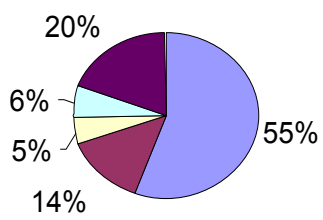

$\square$ Sinkau

$\square$ Tiju

$\square$ Katus

$\square$ Bakle

Others

\section{B. Conversion factor of dry and fresh weight}

Twenty sample tree of different age class (7 yrs and 14 yrs ) and different diameter classes (5$10 \mathrm{~cm}$ and $10-15 \mathrm{~cm}$ ) representing the whole condition of the forest of particular VDC were chosen and felled to measure the fresh as well as air dry weight of bark and foliage. Their total height, diameter over bark (DOB) and diameter under bark (DUB) were recorded and debarked and foliage was collected separately from sampled trees. The fresh weight to air- dried weight ratio of bark is 0.5210 and the fresh weight to air-dried weight ratio of leaf is 0.5721 .

\section{Supply condition of Bark}

From the total volume $\left(0.3027 \mathrm{~m}^{3}\right)$ of the sample tree, air dry weight of bark was $17.06 \mathrm{~kg}$.It is equivalent to $845.391 \mathrm{~kg}$ from $15 \mathrm{~m}^{3}$ volume of Sinkauli stand that was taken from the 98 trees with sampled area 0.14 ha. Since the total forest area was 7.72 ha., total amount of bark that is present in the forest is $4616.94 \mathrm{~kg}$ as the researcher has assumed the average age of the stand to be $9.5 \mathrm{yrs}$, the annual increment of the stand is equal to $87.06 \mathrm{~m}^{3}$ further the researcher has supposed to cut $60 \%$ of the average annual increment of the Cinnamomum tamala stand, almost $52.24 \mathrm{~m}^{3}$ volume of Sinkauli can be harvested annually. Hence from $52.24 \mathrm{~m}^{3}$ of Sinkauli tree volume we can extract 2944.217 $\mathrm{kg}$ bark annually. Last year the price of per $\mathrm{kg}$ 
air dried bark was Rs 80. At the same price, Rs 235520 could be earned annually from the bark only. As from the researches one tree of average age (9.5 yrs) produces $8.53 \mathrm{~kg}$ bark so; about 345 trees have to be cut annually to obtain the harvestable amount of bark.

\section{Supply condition of Foliage}

From this study, $1 \mathrm{~m}^{3}$ of volume of C.tamala tree produces $46.11 \mathrm{~kg}$ of air dried foliage. So, from the total volume of $827.14 \mathrm{~m}^{3}$ of Sinkauli in the $7.72 \mathrm{ha}, 38146.26 \mathrm{~kg}$ of leaves could be produced. As the researcher has assumed to cut $60 \%$ of the average annual increment, only, $2408.78 \mathrm{~kg}$ of leaves can be extracted annually from the Sinkauli forest of this VDC that can earn at least Rs. 108390 at the rate of Rs 45 per $\mathrm{kg}$. For this they have to cut 345 trees of an average age annually.

\section{E. Indigenous management practice of Cinnamomum tamala}

\section{E.1 Nursery practice}

There has not been any commercial enterprise development program of Sinkauli leaves and Dalchini, and there is no massive plantation program of C. tamala. So, well managed and scientific nursery is not available in this VDC. A small scale nursery has been established in Saunepani women community forest user group of ward no. 9, with the support of DFO Syangja. They have been collecting wildlings of Sinkauli and raising seedlings of it and other tree species like, Neem, Bakaino, Ipil-Ipil, Lankuri, and Badahar, but quality of Sinkauli plants were poor because of the lack of proper technical and financial support. Though, they have established the nursery, different practices like irrigation, shading, care and maintenance of fences, weeding, cleaning etc, seemed to be poor.

\section{E.2 Plantation}

Due to the lack of proper awareness program to the whole population of this VDC, some people are not found to be interested about its cultivation .Those people, who are aware and are taking benefit from this species, are bringing wildings from the forest and planting around the homestead and marginal (bare) land .They generally plant wildings during early monsoon period. According to them, this seemed to be a successful practice. There is no huge plantation area except natural stand .Now in some community forest like Jana Hit Paudhure Women Community Forest user group and Saunepani Women Community forest user group have started to plant Sinkauli on bare land.

\section{E.3 SILVICULTURAL / TENDING OPERATION (WEEDING, CLEANING, THINNING, PRUNING)}

The Sinkauli forest is found to be dense and less disturbed. Moreover most Sinkauli forests are private so, they are not conducting proper Silvicultural operations. In the forest area, pruning is natural due to closed canopy and so pole is taller than in the open land, while trees of marginal land are branchy and less tall. They felled the trees periodically according to their need. Cleaning and weeding of the stand is totally absent.

\section{E.4 Harvesting}

\section{a. Bark harvesting}

Harvesting of C. tamala products is generally carried out in two periods i.e. during summer (June-Sept.) and during winter season (Feb. May).The rational behind harvesting during this period is that ease of extraction of bark from the stem. According to the users, the period when tender leaves (red) flourishes in the tree is the appropriate time for extraction of bark. During this period bark could be extracted from branches even smaller than finger size thereby yielding more yields per tree. Harvesting of bark is less 
preferred during November to early February as extraction of bark is almost impossible in this period because the amount of latex is very little and so the sapwood is attached with bark. If, this sapwood portion is mixed with the bark, it will be difficult to remove after drying. For bark harvesting, they simply girdle the tree at the felling portion and debark initially at that portion. Then felling of tree is done by local axe. Once they felled the tree, they cut ring of bark at an interval of 1-2 feet length with local sickle and then debark longitudinally between the ring portions.

\section{B. LEAF COLLECTION}

Generally people do not collect leaves from the forest because there is very low price and there is little market at the local level.So, if they get demand, they collect the leaves by felling whole tree during the bark collection period. Only few farmers are selling air dried leaves. They also use the leaves of Sinkauli as fodder but not so frequently because there is a saying that if they feed much to livestock, they become weaker.

\section{E.5 TOOLS AND TECHNIQUES OF HARVESTING}

The most frequently used tool for felling and trimming the tree is local axe. Sickles are used for cutting branches and separating foliage. Bark extraction can be made by a small knife locally known as siyanhi but local sickles with sharp tip were used more frequently in the bark extraction. For bark extraction, bark is first checked whether it leaves off stem easily by punching with sickle or not. If it releases sufficient latex from punched point, it is concluded that the tree is ready to harvest. If it doesn't release latex and seems dry it is an indicator that the bark cannot be extracted. The presence of new reddish flush of shoots at the top of the tree also determines the time of bark extraction. Some people equipped with knife or sickle climbs up the tree and extracts out bark up to the accessible point by making equal pieces of portable sizes, usually 1-2 feet, to transport to the market. So, sometime whole tree is debarked without felling but in this condition, complete extraction of bark is not possible. To minimize loss of bark, it had better fell tree and bark extraction. The researcher observed that, the best practice is to remove the bark initially from the felling portion. Extraction of the barks of remaining parts of tree is to be carried out only after felling. With the help of knife, ring insertion is made along the length of stem or branch. Then making knife or sickle, movement horizontally and vertically, the bark is released out from the stem.

\section{F PRICE AND MARKETING OF THE PRODUCTS}

There is no market at local level. Farmers have to bring these products to High-way bazaar at Triashi or Rambachha. The farmers are less aware about the actual price of their products. Pricing is mainly done by local contractors or road head traders namely Tuki (Ram Chandra Gurung) and a person from Terai community. The farmer told the researcher those 5-6 years ago, they had sold bark @ Rs. 52-60 but later on, the price has gone down sharply and last year, they had to sell their products only at Rs. 40 local contractors ask them to fell and extract the bark promising to give higher rate but once the farmers have felled and extracted the product, they told that the price has fallen down.

\section{G DEMAND OF DALCHINI AND TEJPAT}

There are only 2-3 local contractors engaged in collection of the Sinkauli products and their ultimate transportation station is Rambachha where a road head trader called Tuki"(Ram 
Chandra Gurung) used to collect and gather for transportation of Dalchini and sometimes Tejpat were accumulated from other VDCs also. According to him, he has been collecting 2-2.5 quintals of its bark from this VDC only. He further added that "I could export any quantity of the products to India, if farmers could bring the products at my home". Since there is only one person being licensed to transport and export from that area, there seems monopoly market. The collected products are exported to India from Butwal and Bhairahawa. The local people said that more and frequent use of Dalchini or Tejpat by human or livestock causes weak to muscles and joints. So, most people only use Tejpat on Tea, Meat, Curry, and Pulaw and few have been using Dalchini as spices. While interviewing with Tuki, about demand, it was found that local farmers even bring barks of khaniu (Ficus cunia) mixing with barks of Sinkauli so exporter deny giving high price. Again demand of thin barks from the branches and coppice shoots is high and their price is accordingly.

\section{H ETHNO-BOTANICAL USE}

Alike with the character of species under Lauraceae family, the species contains ethereal oil in the leaves and cortex of cells (Rendle, 1979) that enrich the plant with aromatic flavor thereby making bark and leaves possible be used as spices and medicine. In Kashmir leaves are used as substitute for pan or betel leaves. It takes in Indian cookery the place of bay leaves in Europe. The eugeonal rich oil is used in place of clove oil in dentifrice and tooth ache. The leaf oil is used in perfumery. The oil shows antibacterial activity, the leaves also contains 3,4,5,7 tetrahydroxy flavones, kaempferol-3-0, glucopyranocide, kaempferol-3-0sophoroside, kaempferol 3, 7-di-orhampnopyranoside and quercetin 3-orutinoside (Kirtikar et al. 1992). Leaves are carminative and are used in colic, diarrhea and rheumatism. They are considered hot and cardiac and are used with long pepper and honey in cough and cold. The leaf powder is considered as distinct hypoglycemic action. Two spoon full of powder is given to diabetic patient four times a day for one month accompanied by controlled diet; significantly, reduce blood sugar level and helps in release or manufacture of more insulin (Kirtikar et al, 1992) It is also given for gonorrhea (Chaudhari and Kayal, n.d; cited in Kirtikar et al, 1992).In India, the leaves are also employed in calico-printing in combination with Myrobalans (Terminalia chebula) and Kamala (Mallotus philippensis).Leaf is bitter-sweetish in taste. It is also useful in scabies, diseases of the anus and rectum, piles, heart trouble. They are good for lever and spleen treatment, sore eyes, stop salvation, stimulant and carminative, find application in rheumatism, colic, diarrhea and scorpion sting.

Bark is useful in gonorrhea, decoction or powder in suppression of lochia after child birth with much benefit. It is used as spices in the Indian subcontinent. Its oil can be used as good remedy for flatulence, paralysis of the tongue, enteralgia and cramps in the stomach and also useful in nausea and vomiting. It destroys the pathogenic bacilli and used internally in typhoid fever. Volatile oil $(2 \%)$, cinnamic acid, resin, tannin, sugar, starch, mucilage, ash; are the major constituents of its bark.

\section{CONCLUSIONS}

From the above analysis and discussion, it can be concluded that Air-dry bark weight to fresh bark weight ratio is found to be 0.5210 . An airdry foliage weight to fresh foliage weight ratio is found to be 0.5721.Bark harvesting is done in summer season because of ease of extraction of bark. Axe, local and indigenous knife were used locally for harvesting of the bark and leaf collection. Farmers are less aware about the 
importance and market price of the Dalchini and Tejpat. No proper silvicultural operations are carried out and no scientific forest management system is applied. As there is almost absence of Sinkauli plants in the National and community forests, proper protection seems needed. Stool coppice system is found to be more beneficial from the production as well as market value of the Sinkauli barks (Dalchini) production. Though 52 trees were selected as seed tree within the VDC area, the farmers could not produce seeds that could be collected, because of the influence of winter migratory bird called as Hukus which eat seeds. According to the questionnaire survey and direct field observation, there is no insect and pest damage found to the Sinkauli stands. Well managed Nursery for sufficient plant production is lacking as it could be an alternative source of income for the rural people. To date, the District Forest Office has not been able to generate revenue from the transportation and exporting of the Dalchini and Tejpat.

Based on the findings, awareness program to motivate the local people for commercial plantation of Sinkauli should be strengthened. Good and dynamic market channel must be established for which government and other line agencies should support technically as well as financially to establish bark and leaf processing units at the local level. Nursery establishment and seedling distribution must be done at local level. If cleaning and thinning operation is carried out and unwanted (7\%) miscellaneous species are removed from the forest and proper operation is done in favor of the desired species, the density of $C$. tamala seemed to be increased.

\section{Sustainable management options and strategies}

Following strategies are suggested to improve sustainable management of Cinnamomum tamala in a way that enhances livelihoods of the forest dependent poor people:

Improve policy to facilitate speedy hand over of even the larger areas of forest and pasture to local user groups.

Identify and cultivate potential tradable species to reduce the growing pressure on CF for collection and trade of Sinkauli, Siltimur, and Timur.

Conduct participatory scientific researches to integrate indigenous as well as scientific knowledge regarding life cycle, ecological requirement, regeneration and ethno botanical uses.

Establish and strengthen collectors' cooperative so that the quantity of Dalchini and Tejpat collection will be high and consequently the bargaining power of the cooperative will be increased.

Develop monitoring systems at both DFO and FUG/ UG levels. Monitoring during and after harvesting should be done carefully by FUG s or collector's association, as well as by DFO and facilitating NGOs

\section{REFERENCES}

Arnold, J.E.M. and M.R. Pierz, (1996): Farming issues relating to Non- Timber Forest Products Research. Workshop proceeding, CIFOR, Indonesia.

Edward, D.M, (1996): Non-Timber forest product, from Nepal.

Gautam, K. and N. N. Devon (2002). Journal of forest and livelihood, Action Aid, Nepal.

GON, (1977): National forestry plan. Ministry of forest and soil conservation, Kathmandu, Nepal.

GON, (1988): Forest law and Bylaws. Ministry of forest and soil conservation, Kathmandu, Nepal.

GON, (1988): Master plan for the forestry sector Nepal. Ministry of forest and soil conservation, Kathmandu, Nepal 
GON/MFSC, (2002): Nepal Biodiversity Strategy. Government of Nepal.

GON-DFRS, (1999): Forest Resources of Nepal (1987- 1998) publication no. 74. Department of Forest Research and Survey and Forest Resource Information System Project, Government of Finland, Embassy of Finland Kathmandu. Nepal.

Jackson, J.K, (1994). Manual of Afforestation in Nepal volume-2.Nepal- UK Forestry Research Project, Kathmandu, Nepal.

Khanal, G. (1997). Management Plan for a Community Forest of Tanhun District. (Research report).

Krebs, C.J, (1978). Ecology; The experimental analysis of distribution and abundance. Second edition. Harper and Row, Publishers. Ojha, H.R, (2002). Current Policy Issues in NTFP Development in Nepal, Proceeding of third regional SEANN workshop on community based NTFP management, OF/ ITTO Pokhara.
Pokhrel, S.K, (1993). Floristic composition, Biomass production and Biomass harvest in the grassland of Royal Bardia National Park, Nepal. Msc. Thesis. Agricultural university of Norway.

Rijal, G, (2001). An assessment of harvesting system of cinnamum tamala in Koldanda VDC of Palpa district. Thesis submitted for the partial fulfillment of Bachelors degree in Institute of Forestry. Pokhara Nepal.

Robert, L.S, (1980). Ecology and Field Biology, Harper and Row Publisher, N. York

Sharma, R. and P. Nath, (1997). Biomass studies. Field method for monitoring Biomass. Oxford and IBH publishing com. Pvt. Ltd. New Delhi.

Tamrakar, P.R and D.J. Danbury, (1997) Silviculture by Rural People in the mid-hills of Nepal, Banko Janakari 7(2): 9-16

(Received 17 July 2017, revised accepted 04 Sept 2017) 